\title{
Experimental canine model for sentinel lymph node biopsy in the vulva using technetium and patent blue dye ${ }^{1}$
}

\author{
Modelo canino experimental para a pesquisa do linfonodo sentinela na vulva usando tecnécio e \\ azul patente
}

\author{
José Ulcijara Aquino ${ }^{\mathrm{I}}$, Luiz Gonzaga Porto Pinheiro" ${ }^{\mathrm{II}}$, Paulo Henrique Diógenes Vasques ${ }^{\mathrm{III}}$, João Ivo Xavier Rocha ${ }^{\mathrm{IV}}$, Diego Alves \\ Cruz $^{\mathrm{IV}}$, Hugo Enrique Orsini Beserrav ${ }^{\mathrm{V}}$, Raissa Vasconcelos Cavalcantev \\ ${ }^{I}$ Master, Department of Surgery, Federal University of Maranhao (UFMA), Sao Luis, Brazil. Involved with technical procedures, analysis and \\ interpretation of data, manuscript writing. \\ IIPhD, Associate Professor, Department of Surgery, Faculty of Medicine, UFC, Fortaleza-CE, Brazil. Design of the study, analysis and interpretation \\ of data, critical revision. \\ IIIFellow Master degree, Postgraduate Program, Department of Surgery, UFC, Fortaleza-CE, Brazil. Helped with technical procedures, acquisition of \\ data. \\ ${ }^{\mathrm{IV}}$ Graduate student, Medicine Faculty, UFC, Fortaleza-CE, Brazil. Analysis and interpretation of data, statistical analysis, manuscript writing. \\ ${ }^{\vee}$ Graduate students, Veterinary Faculty, State University of Ceara (UECE), Brazil. Animal care and acquisition of data.
}

\begin{abstract}
PURPOSE: This paper aims to study and define the experimental model of sentinel lymph node biopsy of the vulva in bitches.

METHODS: $0.2 \mathrm{ml}$ of 99mTc phytate was injected intradermally, using a fine gauge insulin needle in the anterior commissure of the vulva. Thirty minutes after 99mTc injection, the inguinal mapping was performed using a gamma probe. After this, 0.5 ml of blue dye (bleu patenté V Guerbet 2.5\%) was injected in the same place. After 15 minutes, a $3 \mathrm{~cm}$ long inguinal incision was made at point maximum uptake followed by careful dissection, guided by visualization of a bluish afferent lymphatic system that points to the sentinel lymph node (SLN).
\end{abstract}

RESULTS: It was observed that $88 \%$ of SLN were identified. It wasn't found a significant difference among the presence or not of sentinel lymph node in the sides, which is an indication of a good consistency. It was observed a high ( $88 \%)$ and significant ( $\square 2=12.89$ and $\mathrm{p}=0.0003$ ) intercession between both methods (blue dye and radiation).

CONCLUSION: The experimental model adopted is feasible, becoming advantageous in applying the association of Patent blue and 99mTc.

Key words: Vulvar Neoplasms. Sentinel Lymph Node Biopsy. Technetium. Animal Experimentation. Dogs.

\section{RESUMO}

OBJETIVO: Definir um modelo experimental para a pesquisa do linfonodo sentinela na vulva de cadelas.

MÉTODOS: 0,2 ml de tecnécio diluído em fitato (99mTc) foi injetado por via intradérmica na comissura anterior da vulva. Trinta minutos após a injeção de 99mTc, o mapeamento inguinal foi realizada utilizando uma sonda gama. Após isto, 0,5 ml de corante azul (bleu Patente Guerbet V 2,5\%) foram injetados no mesmo lugar. Após 15 minutos, uma incisão inguinal de três centímetros foi feita no ponto de captação máxima seguido de dissecção cuidadosa, guiada através da visualização de um sistema linfático aferente corado em azul que apontava para o linfonodo sentinela (LS).

RESULTADOS: Foi observado que em 88\% das vezes o LS foi identificado. Não foi encontrada diferença significativa entre a presença ou não de linfonodo sentinela nos lados direito e esquerdo, o que é uma indicação de uma boa consistência do método. Foi observada uma alta ( $88 \%$ ) e significativa ( $\square 2=12,89$ e p =0,0003) intercessão entre os dois métodos (corante azul e radiação).

CONCLUSÃO: O modelo experimental adotado é viável, tornando-se vantajoso na aplicação da associação de Azul Patente e 99mTc. Descritores: Neoplasias Vulvares. Biópsia de Linfonodo Sentinela. Tecnécio. Experimentação Animal. Cães. 


\section{Introduction}

In 1977 Cabanas $^{1}$ reported the identification of nodal drainage pathways and a sentinel node from penile cancer. Sentinel lymph node (SLN) biopsy, introduced in the mid-1990s has revolutionized the management of breast cancer patients ${ }^{2,3}$. The use of this method has reduced significantly the need for extensive axillary dissection in order to establish a reliable prognosis in breast cancer treatment.

Morton et al. ${ }^{4}$ using isosulfan blue dye demonstrated the accuracy of sentinel node biopsy for nodal staging and management of patients with primary cutaneous melanoma. The authors determined that if the sentinel node tumor was not committed by tumor the other nodes in the lymphatic network draining would also be healthy, and reported a $1 \%$ rate of false negatives, opening prospects for research in the world. ${ }^{5-7}$

In 1993, Alex et al. ${ }^{8}$ injected technetium and introduced the technique of gamma probe-guided surgery to identify the sentinel node. In the same year, Krag et al. ${ }^{9}$ published a study on sentinel node using Technetium-99 (Tc99) associated with the use of probes for detection of gamma rays in breast cancer. They concluded that the radiolocation and selective resection of sentinel lymph node was feasible and could be used to foresee lymph node status.

Vulvar cancer accounts for less than $1 \%$ of cancer in women accounting for $3 \%$ to $5 \%$ of female genital tumors ${ }^{10-12}$. It is highly curable when diagnosed early. Traditionally, treatment of vulvar cancer is surgery ${ }^{13-16}$. The knowledge of the lymphatic drainage of the organ is essential to understand which type of surgery is appropriate for each case $\mathrm{e}^{15,16}$. At the beginning of the century, women were just submitted to local resection. It was recommended the adoption of surgical techniques in a single block with removal of the vulva with wide surgical margins beyond the tumor and inguinal regions using a single incision ${ }^{11,13,17,18}$. Today, some authors question the need for complete resection of the vulva and inguinal regions. Although the survival rate of women with negative inguinal lymph nodes is very good, patients who develop recurrences in lymph nodes not removed during initial surgery have a high mortality ${ }^{19}$. Thus, other authors have attempted less aggressive techniques to perform lymph node dissection as not recommending to extend the resection beyond the lateral anterior superior iliac spine, suggesting the preservation of the fascia lata and saphenous vein and advocating for the removal and freezing of the sentinel node as a promising staging ${ }^{17,18}$.

In literature there are few studies and experimental models specific to the research and learning of this technique ${ }^{20}$, which has ample opportunity to establish precise surgical approach to the lymphatic chain. This way you can avoid unnecessary dissection and recurrence, avoiding much comorbidity.

The choice of animal breed of Canis familiaris was made because of the similarity between their lymphatic drainage to the human. The superficial inguinal lymph nodes in dogs are called mammary lymph nodes because they drain the breast area of the breast flow pairs. In the female, however, the lymphatic vessels are also draining the vulva and clitoris ${ }^{21}$.

This paper aims to study and define the experimental model of sentinel lymph node biopsy of the vulva in bitches, with the use of patent blue to identify the sentinel node and Phytate Technetium (99mTc) to map the lymphatic drainage.

\section{Methods}

All studies were conducted according to the rules of the Brazilian College of Animal Experimentation (COBEA). The use of the radioactive tracer Technetium99 (Tc99) was approved by the local authorities. Approval for experimental use of laboratory animals was obtained from the Committee of Ethics in Animal Research of the Federal University of Ceara.

Sample - The sample consisted of 25 healthy bitches undefined breed, species Canis familiaris, housed in the Zoonosis Control Center Kennel of the City of Fortaleza. Inclusion criteria - Clinically healthy bitches. Exclusion criteria - Animals under six months old, with less than $5 \mathrm{~kg}$ or over $15 \mathrm{~kg}$ and presenting previous surgery and/or scars were excluded.

As radiotracer, we used $0.2 \mathrm{~mL}$ of $99 \mathrm{mTc}$ phytate (National Council of Nuclear Energy, Brazil).

\section{Surgical procedure}

After immobilization on the operating table with legs abducted, the animal was anesthetized with atropine (Centralvet ${ }^{\circledR}$, Brazil) $\quad 0.05 \mathrm{mg} / \mathrm{kg}$ subcutaneously followed by Ketamine hydrochloride (Syntec ${ }^{\circledR}$, Brazil) $15 \mathrm{mg} / \mathrm{Kg}$ and xylazine hydrochloride $1.5 \mathrm{mg} / \mathrm{Kg}$ (Syntec ${ }^{\circledR}$, Brazil) intramuscularly. The level of anesthesia was monitored continuously by clinical parameters such as movements of the nostrils and other muscle groups, respiratory and cardiac rates. Additional anesthesia was provided as required. Venipuncture in an upper paw, with the 9 or 21 gauge "scalp” needles was performed for administration of saline $0.9 \%$ to secure adequate venous access.

Surgical areas of the anterior commissure of the vulva of the bitch were shaved to remove excess hair. Following, 99mTc 
phytate $0.2 \mathrm{ml}$ was injected intradermally, using a fine gauge insulin needle in the anterior commissure of the vulva, cutaneousmucous transition (Figure 1). Two-minute bidigital massage was provided to promote the migration and transport of radiocolloid particles to the lymphatic system.

Thirty minutes after 99mTc injection, the inguinal mapping was performed (Figure 2), using a gamma probe, NuclearLab-DGC-8, covered with surgical glove, in order to identify the location of the point maximum uptake of gamma radiation in the inguinal region representing the projection of the sentinel node.

After this, $0.5 \mathrm{ml}$ of blue dye (bleu patenté V Guerbet $2.5 \%)$ was injected in the anterior commissure of the vulva, cutaneous-mucous transition (Photo 3). Local compression and gentle massage at the site of injection were applied to prevent the contrast to spread further and to allow it to be transported by the lymphatic network of the area to the sentinel node.

After 15 minutes, a $3 \mathrm{~cm}$ long inguinal incision was made at point maximum uptake followed by careful dissection (Figure 4), guided by visualization of a bluish afferent lymphatic system that points to the SLN(s). When the afferent lymphatic vessels were difficult to identify, the location of the SLN with the gamma probe was very important to avoid severance of the lymphatic drainage (Figure 5).

A significant radioisotope uptake should be at least 5 fold higher than the background radioactivity in the armpit. The background radioactivity represents the count obtained in four axillary equidistant points from the point of injection or the location of the sentinel node.

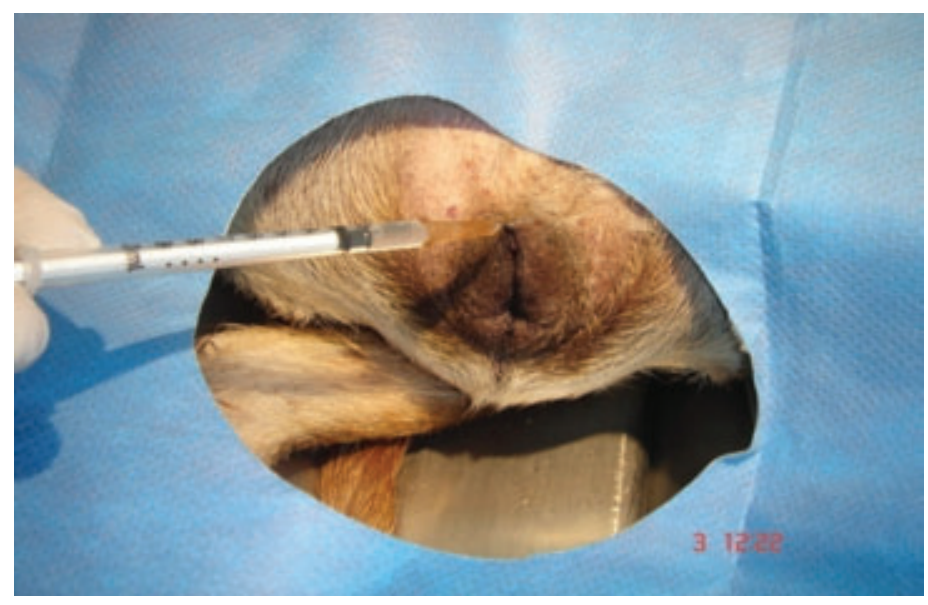

FIGURE 1 - Intradermal injection of 99mTc into the anterior commissure of the vulva using a fine-gauge insulin needle.

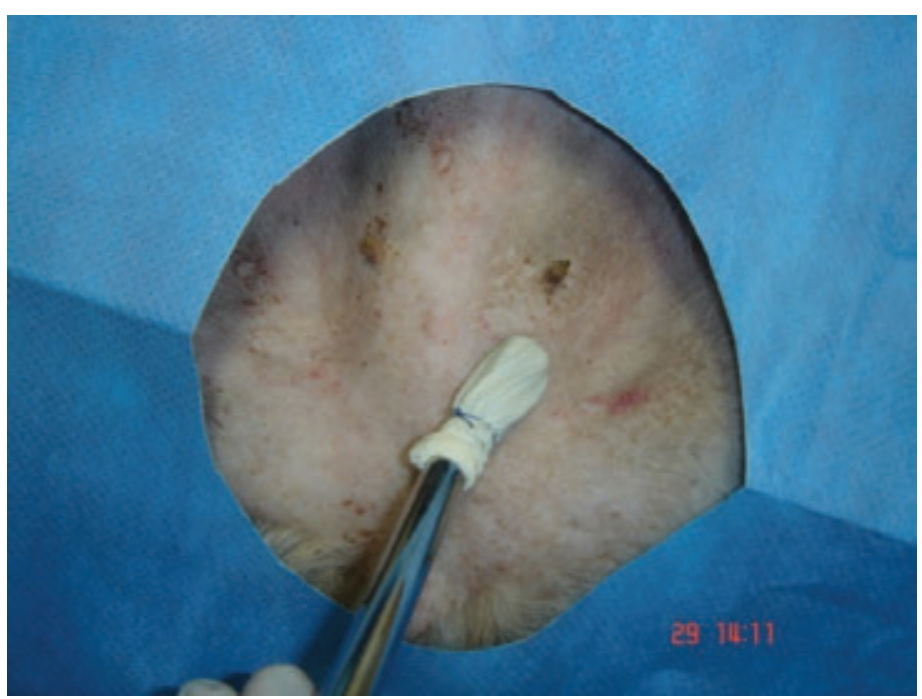

FIGURE 2 - Performing mapping using a gamma probe to identify the location of the sentinel node

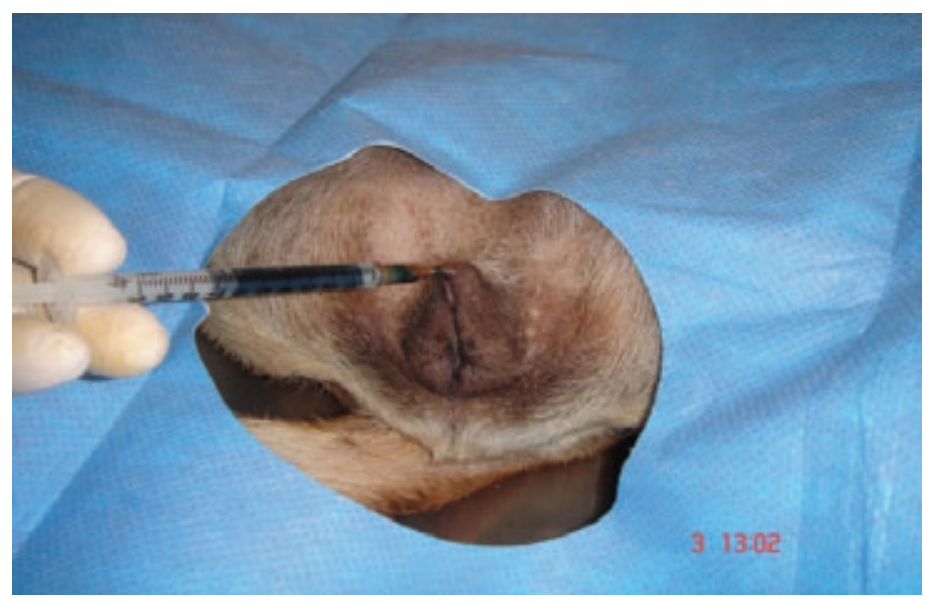

FIGURE 3 - Intradermal injection of blue dye (blue patente V Guerbet $2.5 \%$ ) into the anterior commissure of the vulva using a fine-gauge insulin needle.

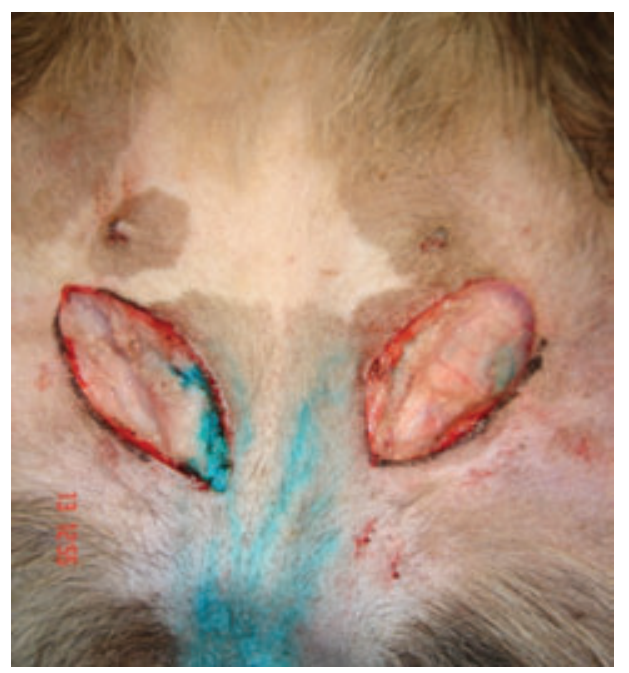

FIGURE 4 - Long inguinal incision at point of maximum uptake. 


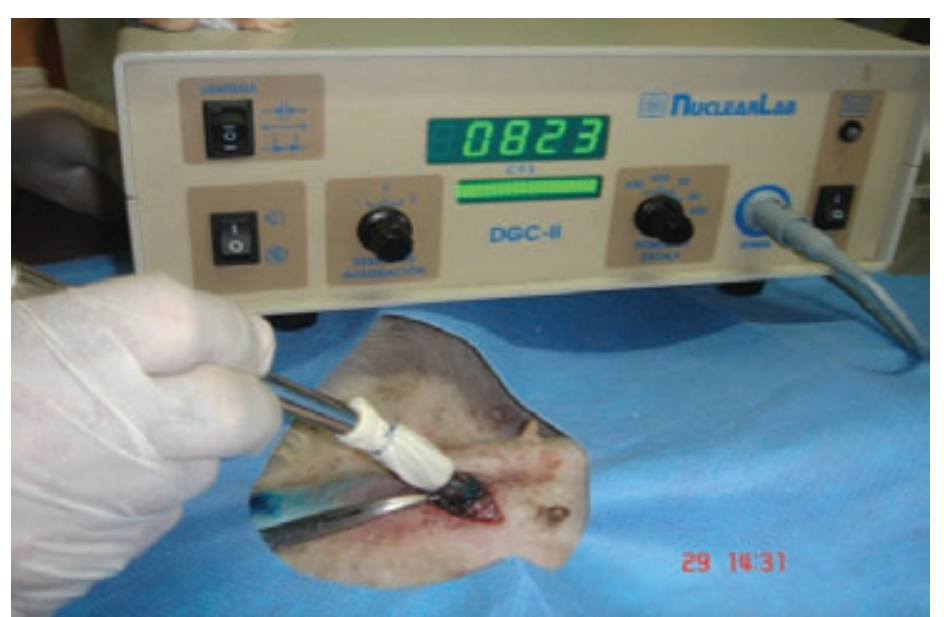

FIGURE 5 - Measurement the radiocolloid uptake in vivo looking for the removal of the SLN.

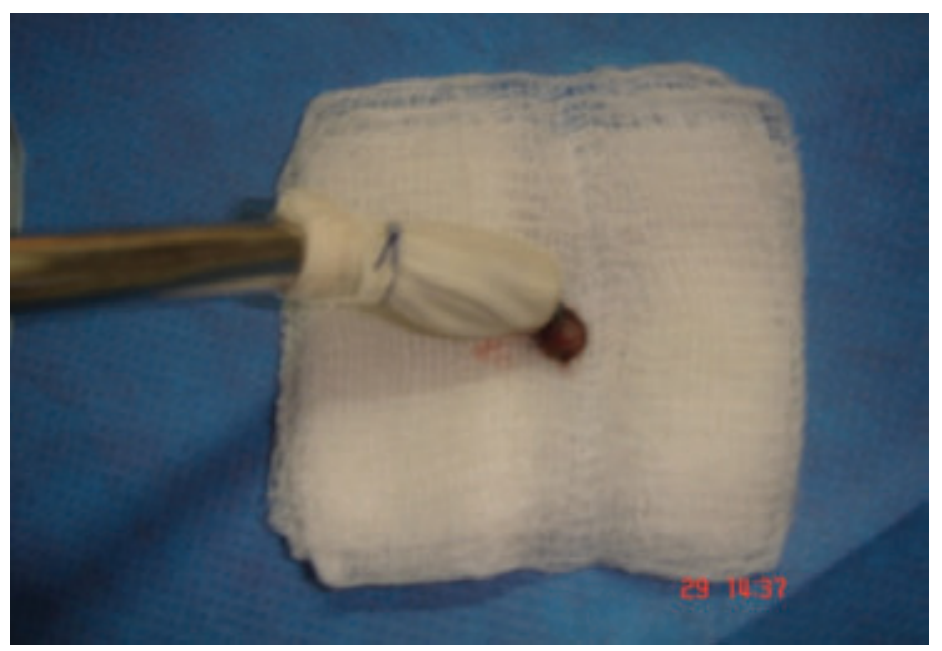

FIGURE 6 - Measurement the radiocolloid uptake ex vivo after the removal of the SLN.

Upon complete exposure of the identified SLN the radiocolloid uptake was measured in vivo and ex vivo after the removal of the SLN (Figure 6). Values obtained were registered for posterior analysis. The position of the sentinel lymph node, identified by the blue dye, was compared with the location identified by the gamma probe to check whether there was agreement between the two methods. Radiation was also measured in the surgical bed to identify any remaining hot lymph nodes. If positive, the lymph node was removed and recorded as to the characteristics of radiation and dye uptake. The area ratio of greater uptake / background radiation of the surgical bed should be equal to or greater than ten. Verification of the radioactivity of the SLN removed from the surgical field (ex-vivo counting) and comparison with radiation from the surgical bed, confirm that the SLN was actually removed and there is no other source of radiation that can justify the continuation of search for another node.

We recorded all radiation rates at the injection site before incision, sentinel lymph node radiation in vivo and ex vivo and the radiation from the central bed where the sentinel node was located. The parameter used was the background radioactivity (radiation control). The tabulated data quantified the intersection between the two markings and the correlation between the methods.

The animal was sacrificed after the experiment with rapid intravenous injection of potassium chloride to $10 \%$, stored in suitable plastic bag, placed in refrigeration for at least two hours, and subsequently sent to the Zoonosis Control Center Kennel for final destination.

\section{Statistical methods}

Data were analyzed using SPSS for Windows 16.0 (2007). Initially, we determined whether there were differences between the procedures of the left and right side of the animal, by chi-square test and t test for paired samples. Later, we analyzed the relationship between numerical variables (radiation in the commissure, radiation in the inguinal incision, counting in vivo and ex vivo) by Pearson correlation. In all tests, the level of significance to reject the null hypothesis was $5 \%$, ie, were considered significant when $\mathrm{p}<0.05$.

\section{Results}

From a sample of 25 bitches, whereas the method was applied in both inguinal lymphatic chains, 88\% (44/50) of bitches studied had a SLN identified using the gamma probe after injection of Tc99 phytate in the commissure region $\left(\square^{2}=28.88\right.$ e $\left.\mathrm{p}<0.0001\right)$. After injection of patent blue, 80\% (40/50) of the isolated lymph nodes were stained (Table 1). In the cases studied, there was agreement among the methods evaluated in $88 \%$ (44/50) of cases $\left(\square^{2}=12.89\right.$ e $\left.\mathrm{p}=0.0003\right)$. 
TABLE 1 - Chi-square test comparing the right and left sides.

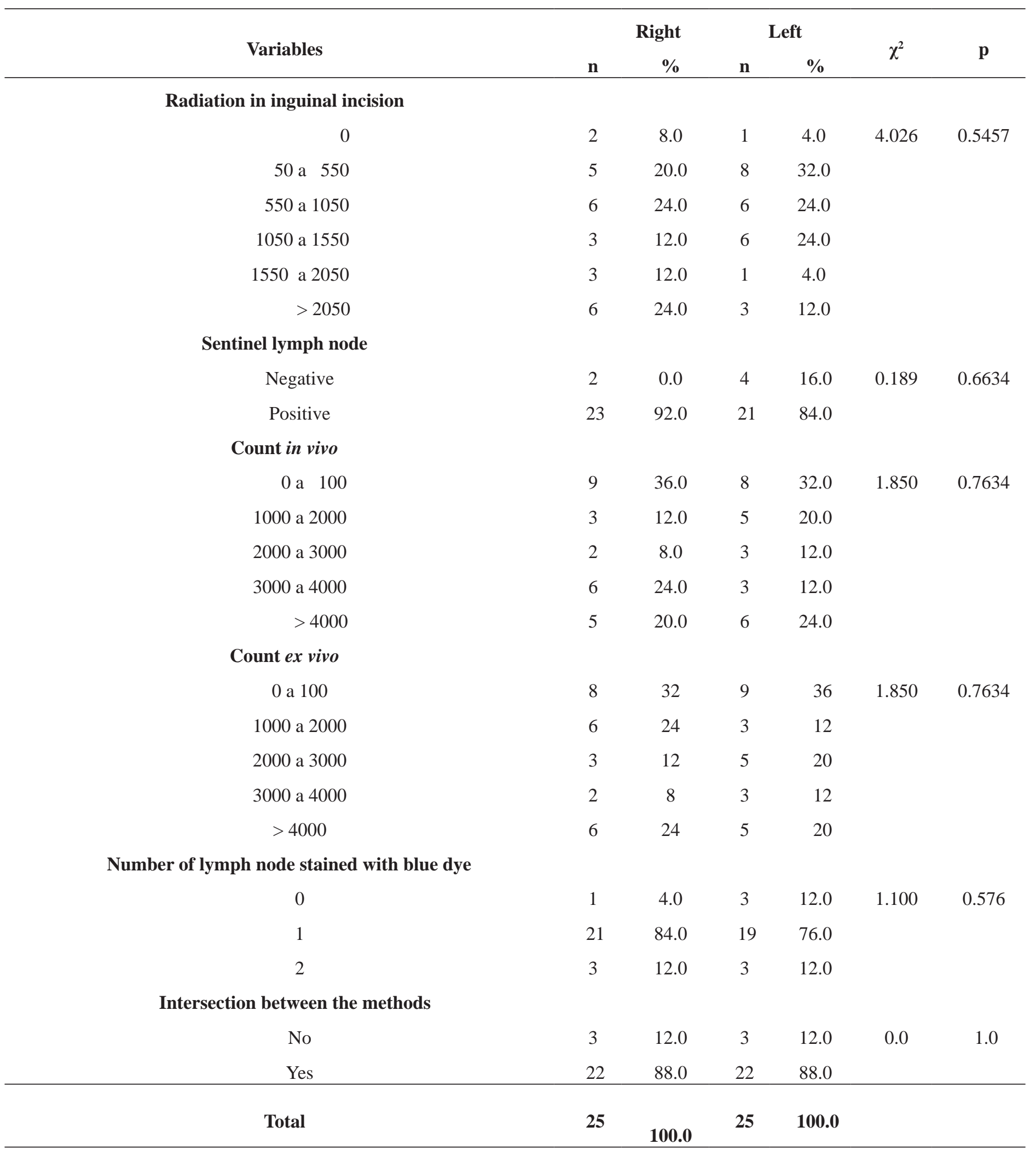


There was no statistically significant difference between right and left sides regarding the number of lymph nodes stained or radiolabeled, the amount of radiation measured in the commissure, in the inguinal incision site and in the counts in-vivo and ex vivo (Table 1).

We observed a significant negative relationship between weight bitch and radiation in the commissure, i.e., higher weights predicts lower scores (Table 2).

TABLE 2- Student's t-test comparing the radiation at the incision site, ex vivo and in vivo lymph node in both sides.

\begin{tabular}{cccccccc}
\hline & & N & Mean & $\begin{array}{c}\text { Standard } \\
\text { deviation }\end{array}$ & t & p \\
\hline $\begin{array}{c}\text { Radiation in } \\
\text { inguinal incision }\end{array}$ & Right & 23 & 2135.7 & 3659.25 & 1.692 & 0.105 \\
& Left & 23 & 1196.74 & 1316.489 & & \\
Count in vivo & Right & 23 & 3241.13 & 3813.696 & -0.119 & 0.906 \\
& Left & 23 & 3343.7 & 3219.254 & & \\
Count ex vivo & Right & 23 & 3524.65 & 4409.27 & 0.816 & 0.423 \\
& Left & 23 & 2776.48 & 2588.68 & & \\
\hline
\end{tabular}

\section{Discussion}

It was Cabanas et al. ${ }^{1}$ that renewed interest in studying the lymphatic drainage in malignant neoplasms, in order to find a way to precisely define the need for radical lymph node dissection.

Perhaps the most important research related to lymphatic drainage in breast cancer was performed before the advent of the modern concept of the sentinel node ${ }^{22}$. These surveys were carried out to inject the blue dye in breast subareolar region, about 20 hours before the radical mastectomies, in order to show the lymphatic channels and nodes to be resected safely. It was observed that in some cases, this drainage was so superficial that, if the flap was a little thicker, it runs the risk of not drying it completely.

Morton et al. ${ }^{4}$ were responsible for the recent worldwide spread of the sentinel node technique through its application in melanoma. In their clinical study, they documented the preliminary results of the sentinel lymph node surgery in 223 patients with melanoma and clinically negative regional lymph nodes. The sentinel node was identified by injecting blue dye in $82 \%$ of patients with false negative rate of $1 \%$, comparing with the results of lymph node dissection. After the initial publication of these data in 1992, a number of other subsequent studies have validated the technique, which is now widely accepted ${ }^{23}$.

The concept of sentinel lymph node (SLN) is now widely validated for breast cancer and melanoma. The disease status of the SLN reflects the reality of the entire drainage area of the lesion ${ }^{24}$. This concept applied to cancer of the vulva could benefit many patients with a more precise surgery with less morbidity and better quality of life.

Among the techniques of lymphatic mapping and SLN detection, the use of radiocolloids and the use of gamma-probe (radioguided surgery), associated or not to patent blue dye, have shown the best results ${ }^{18}$.

As the anatomical and physiological lymphatic drainage of the human vulva and the dog, it was held to identify the sentinel node identifying the presence of radiation by injecting 99mTc in the inguinal region and injecting patent blue in the vulvar transition of skin and mucosa. It is observed that there was presence of sentinel lymph node in $88 \%$. Regardless of right or left side, a significant difference was found ( $\left.\square^{2}=28.88, \mathrm{p}<0.0001\right)$ between the presence or absence of sentinel lymph node.

We observed a high (88\%) and significant $\left(\square^{2}=12.89\right.$, $\mathrm{p}=0.0003$ ) intersection between the methods (blue dye and radiation), and was not observed (see Table 2) significant difference $(\mathrm{p}>0.05)$ between the left and right sides, indicating a good consistency in the procedures.

Since 99mTc was introduced in the diagnostic procedures in nuclear medicine, he has been the most widely used radionuclide. The $99 \mathrm{mTc}$ is convenient for medical routine appointment at various radiopharmaceuticals due to their favorable characteristics, such as getting good pictures in scintillation cameras and convenient means of producing at a reduced cost.

In our study there was no significant difference $(p>0.05)$ in mean of the numerical variables of radiation in inguinal incision, in vivo counting and ex vivo counting in the right and the left sides, indicating that the procedure was carried out similar on both sides.

The Patent Blue V was chosen because it is a drug that diffuses in a few minutes in veins and lymphatic vessels, with a bluish color, selecting the territory of vascular tissues. The Patent Blue $\mathrm{V}$ is used worldwide in sentinel lymph node procedures in breast cancer.

Morton et al. ${ }^{4}$ were the pioneers of this technique, having initially carried out in cats showing two vital stains more effective: blue esosulfam (lymphazurim) and patent blue (sodium salt of patent blue V), which are now used clinically. The lymphatic mapping with patent blue anatomically and functionally mimics 
the way that the neoplastic cell could have gone to the lymphatic region from the primary tumor, allowing their identification ${ }^{20}$.

The dog was the animal chosen for its ease of acquisition, manipulation and size besides the anatomical similarities of the inguinal region between the dog and human.

\section{Conclusions}

The experimental model adopted in the sentinel lymph node in the human's vulva is feasible, making it advantageous when combined Patent Blue and 99mTc. The identification of the sentinel lymph node is feasible with patent blue, and lymphatic mapping with 99mTc demonstrates excellent results in identifying the lymphatic drainage of the vulva of bitches.

\section{References}

1. Cabanas RM. An approach for the treatment of penile carcinoma. Cancer. 2000;39:456-66.

2. Giuliano AE. Sentinel lymphadenectomy in primary breast carcinoma: an alternative to routine axillary dissection. J Surg Oncol. 1996;62:75-7.

3. Albertini JJ, Lyman GH, Cox C, Yeatman T, Balducci L, Ku N, Shivers S, Berman C, Wells K, Rapaport D, Shons A, Horton J, Greenberg H, Nicosia S, Clark R, Cantor A, Reintgen DS. Lymphatic mapping and sentinel node biopsy in the patient with breast cancer. JAMA. 1996;276:1818-22.

4. Morton DL, Wen DR, Wong JH, Economou JS, Cagle LA, Storm FK, Foshag LJ, Cochran AJ. Technical details of intraoperative lymphatic mapping for early stage melanoma. Arch Surg. 1992;127:392-9.

5. Oliveira Filho RS, Santos ID, Ferreira LM, de Almeida FA, Simões e Silvia Enokihara MM, Barbieri A, Tovo Filho R. Is intra-operative gamma probe detection really necessary for inguinal sentinel lymph node biopsy? Sao Paulo Med J. 2000;118:165-8.

6. Udi C. Axillary node sample to evaluate the axilla. World J Surg. 2001;25:773-9.

7. Oliveira Filho RS, Silva AM, Hochman B, Oliveira RL, Arcuschin L, Wagner J, Yamaga LY, Ferreira LM.. Vital dye is enough for inguinal sentinel lymph node biopsy in melanoma patients. Acta Cir Bras. 2006;21:12-5.

8. Alex JC, Weaver DL, Fairbank JT, Rankin BS, Krag DN. Gammaprobe-guided lymph node localization in malignant melanoma. Surg Oncol. 1993;2:303-8.

9. Krag DN, Weaver DL, Alex JC, Fairbank JT. Surgical resection and radiolocalization of the sentinel lymph node in breast cancer using a gamma probe. Surg Oncol. 1993;335-9; discussion 340.

10. Pinheiro LGP, Moraes MO, Soares AH, Lopes, AJT, Naguére MASP, Gondim FAL, Brandão CB, Nascimento, DCH, Soares, JPH, Silva JMM. Estudo experimental de linfonodo sentinela na mama da cadela com azul patente e Tecnésio Tc99m. Acta Cir Bras. 2003;18(6):514-6.

11. Coleman RL, Santoso JT. Vulvar carcinoma. Curr Treat Opion Oncol. 2000;1:177-90.

12. Verdiani LA, Juliato CR, Derchain SFM. Carcinoma da vulva: epidemiologia e aspectos clínicos. Rev Centro Referência 1997;2:86-90.

13. Di Saia PJ, Creasman WT. Invasive cancer of the vulva. Clinical gynecologic oncology. 4ed. St. Louis: Mosby Year Book; 1993.
14. Monaghan JM. The management of carcinoma of the vulva. In: Sheperd JD, Monaghan JM (eds). Clinical gynecologic. 2ed. London: Blackwell; 1990. p.140-67.

15. Taussig FJ. A study of limph glands in cancer of the cervix and cancer of the vulva. Am J Obstet Gynecol. 1958;36:1319.

16. Way S. The surgery of vulvar carcinoma: an appraisal. Clin Obstet Gynaecol. 1978;5:623-8.

17. Micheletti L, Levi AC, Bogliatto F, Preti M, Massobrio M. Rationale and definition of the lateral extension of the inguinal lymphadenectomy for vulvar cancer derived from an embriological and anatomical study. J Surg Oncol. 2002;81:19-24.

18. de Hullu JA, van der Zee AG. Sentinel node techniques in cancer of the vulva. Curr Womens Health Rep. 2003;3:19-26.

19. Scheistroen M, Nesland JM, Trope C. Have patients with early squamous carcinoma of the vulva been overtreated in the past? The norvegian experience 1977-1991. Eur J Gynaecol Oncol. 2002;23:93-103.

20. Pereira CT. Avaliação cintilográfica da vascularização e drenagem linfática de glândulas mamárias de cadelas. Universidade de São Paulo, 2005.

21. Getty RS. Anatomia dos animais domésticos. 5ed. Rio de Janeiro: Guanabara Koogan; 1975.

22. Haagensen CD, Feind KR, Herter FP, Slanetz CA, Weinberg JA. The lymphatics in cancer. Philadelphia: WB Saunders; 1972.

23. Cochran AJ, Balda BR, Starz H, Bachter D, Krag DN, Cruse CW, Pijpers R, Morton DL. The Augsburg consensus: techniques of iymphatic mapping, sentinel iymphadenectomy, and completion lymphadenectomy in cutaneous malignancies. Cancer. 2000;89(2):236-41.

24. Sohaib SA, Mokovic EC. Imaging in vulval cancer. Best Pract Res. Clin Obstet Gynaecol. 2003;17(4):543-56.

\section{Correspondence:}

Luiz Gonzaga Porto Pinheiro

Departamento de Cirurgia

Rua Professor Costa Mendes, 1608/ $3^{\circ}$ andar

60430-140 Fortaleza - CE Brasil

Tel.: (55 85)3366-8063

Fax: (55 85)3283-7851

luizgporto@uol.com.br

Received: September 14, 2011

Review: November 16, 2011

Accepted: December 12, 2011

Conflict of interest: none

Financial source: none

${ }^{1}$ Research performed at Experimental Animal Laboratory of Department of Surgery, Faculty of Medicine, Federal University of Ceara (UFC), Fortaleza, Brazil. 